\title{
Angiotensin converting enzyme inhibition reduces retinal overexpression of vascular endothelial growth factor and hyperpermeability in experimental diabetes
}

\author{
R.E. Gilbert ${ }^{1}$, D.J.Kelly ${ }^{1}$, A.J.Cox ${ }^{1}$, J. L.Wilkinson-Berka ${ }^{2}$, J. R.Rumble ${ }^{1}$, T. Osicka ${ }^{1}$, S. Panagiotopoulos ${ }^{1}$, V.Lee ${ }^{1}$, \\ E.C.Hendrich ${ }^{1}$, G.Jerums ${ }^{1}$, M. E. Cooper ${ }^{1}$ \\ ${ }^{1}$ University of Melbourne Department of Medicine (Austin and Repatriation Medical Centre) Victoria, Australia \\ ${ }^{2}$ University of Melbourne Department of Physiology, Victoria, Australia
}

\section{Abstract}

Aims/hypothesis. Angiotensin converting enzyme (ACE) inhibition has been recently suggested to have retinoprotective actions in diabetic patients but the mechanism of this effect is not known. In vitro, angiotensin II stimulates expression of vascular endothelial growth factor (VEGF), a permeability-inducing and endothelial cell specific angiogenic factor which has been implicated in the pathogenesis of diabetic retinopathy in humans and in experimental animals. We sought to determine the effects of ACE inhibition on retinal VEGF expression and permeability in experimental diabetic retinopathy.

Methods. Streptozotocin-induced diabetic rats and control animals were assigned at random to receive ACE inhibitor treatment or vehicle. At 24 weeks the retinal VEGF protein gene expression was assessed by northern blot analysis and in situ hybridisation. Retinal permeability to albumin was measured using a double isotope technique.
Results. Experimental diabetes was associated with cell specific two to fourfold increase in retinal VEGF protein gene expression $(p<0.01)$ and a 2fold increase in retinal vascular permeability to albu$\min (p<0.01)$. The localization of VEGF expression in the retina was not altered in animals with experimental diabetes. Angiotensin converting enzyme inhibitor treatment of diabetic rats reduced diabetesassociated changes in VEGF gene expression and vascular permeability.

Conclusion/interpretation. These findings implicate the renin-angiotensin system in the VEGF overexpression and hyperpermeability which accompany diabetic retinopathy and provide a potential mechanism for the beneficial effects of ACE inhibition in diabetic retinal disease. [Diabetologia (2000) 43: 1360-1367]

Keywords Retina, vascular endothelial growth factor, permeability, angiotensin converting enzyme.
Despite laser photocoagulation therapy, diabetic retinopathy remains a common cause of visual impairment and blindness [1], principally as a consequence of proliferative retinopathy and macular oedema. Al-

Received: 5 June 2000 and in revised form: 27 July 2000

Corresponding author: Dr. R. E. Gilbert, MBBS PhD FRACP, University of Melbourne Department of Medicine, St. Vincent's Hospital, 41 Victoria Parade, Fitzroy, Victoria, 3065, Australia

Abbreviations: ACE, angiotensin converting enzyme; AII, angiotensin II; RAS, renin-angiotensin system; VEGF, vascular endothelial growth factor; SD, Sprague-Dawley; STZ, streptozotocin; OD, optical density. though the pathogenesis of these retinal disorders characterized by retinal neovascularization and exudation is incompletely understood, recent evidence has implicated the vascular endothelial growth factor (VEGF), a permeability-inducing and endothelial cell selective angiogenic glycoprotein as a key factor [2-4].

Although plasma renin is suppressed in diabetes, experimental evidence suggests that the tissue reninangiotensin system (RAS) is activated in the setting of chronic hyperglycaemia [5] and that its blockade underlies the beneficial effects of angiotensin converting enzyme (ACE) inhibition in diabetic nephropathy [6] and cardiovascular disease [7]. Previous 
studies have shown that components of the renin-angiotensin system are also present in the retina [8] and that the severity of retinopathy correlates with the activity of the RAS $[9,10]$. More recently, treatment of diabetic patients with the angiotensin converting enzyme inhibitor, lisinopril has been shown to reduce both the rate of progression of non-proliferative retinopathy and the development of proliferative changes [11].

In vitro studies have shown that angiotensin II (AII) directly stimulates the secretion of VEGF in cultured vascular smooth muscle [12] and in cardiac endothelial cells [13]. Whether this relation between the RAS and VEGF secretion applies to the in vivo setting has not, however, been examined. Accordingly, our study sought to determine whether the beneficial effects of ACE inhibition in experimental diabetic retinopathy is mediated by changes in retinal VEGF expression.

\section{Materials and methods}

Animals. Experimental studies were conducted in two stages. Experiment 1 was conducted to determine changes in retinal VEGF gene expression as assessed by northern blot analysis. The aims of Experiment 2 were fourfold. Firstly, to assess the effects of ACE inhibition on retinal vascular permeability. Secondly, to determine the pattern of VEGF mRNA distribution in the eye. Thirdly, to confirm the findings of northern analysis on retinal gene expression using a complimentary technique and fourthly to assess whether another ACE inhibitor, perindopril, had similar effects to those of ramipril.

In Experiment 1, twenty-four male Sprague Dawley (SD) rats aged 8 weeks, weighing between 200 and 250 grams were assigned at random to receive streptozotocin (STZ, $n=12)$ at a dose of $45 \mathrm{mg} / \mathrm{kg}$ (diabetic) or citrate buffer alone (control, $n=12$ ). Both control and STZ-diabetic rats were further selected at random to receive either the ACE inhibitor, ramipril (Hoechst Marion Roussel, Frankfurt, Germany) $1 \mathrm{mg} / \mathrm{l}$ in drinking water or untreated drinking water. All rats were given free access to standard chow containing $20 \%$ protein (Clark, King \& Co., Melbourne, Australia). Only STZ-treated animals with plasma glucose concentrations above $15 \mathrm{mmol} / \mathrm{l}$ were considered diabetic and included in the study. Diabetic animals were treated with 6 units insulin zinc suspension (Ultratard HM, Novo Nordisk, Bagsvaerd, Denmark) injected subcutaneously three times a week to maintain body weight and improve long-term survival. Rats were assigned at random to receive either STZ $(n=12)$ or citrate buffer $(n=12)$. Animals were killed at 24 weeks. In the six rats from each group (control, control + ramipril, diabetic, diabetic + ramipril) eyes were enucleated immediately after death and the retinae isolated by blunt dissection using a dissecting microscope. Retinae were then frozen in liquid nitrogen and stored at $-80^{\circ} \mathrm{C}$ for subsequent northern analysis.

To further assess the effects of ACE inhibition on retinal VEGF expression, another study was done (Experiment 2). As in Experiment 1, rats $(n=48)$ were assigned at random to receive either STZ $(n=24)$ or citrate buffer $(n=24)$. Both control and STZ-diabetic rats were then further selected at random to receive either the ACE inhibitor, perindopril (Servier, Neuilly, France) $2 \mathrm{mg} / \mathrm{l}$ in drinking water or untreated drinking water. For $24 \mathrm{~h}$ before they were killed animals were housed in metabolic cages for subsequent measurement of urinary albumin excretion rate using a coated tube radioimmunoassay [14]. At 24 weeks, six rats in each of the four groups (control, control with perindopril diabetes, diabetes with perindopril) underwent assessment of vascular permeability. The remaining 24 rats were decapitated after which both eyes were enucleated and blood was collected for measurement of plasma glucose concentration by glucose oxidase technique [15], haemoglobin $A_{1 c}$ by HPLC [16] and hematocrit by automated cell counter. The left eye of the remaining six rats in each group was immersion-fixed in $10 \%$ neutral buffered formalin and was subsequently embedded in paraffin for in situ hybridization studies.

All experimentation was approved by the animal ethics committee of the Austin and Repatriation Medical Centre.

Northern blot analysis. Retinae from animals stored at $-80^{\circ} \mathrm{C}$, outlined in Experiment 1 were homogenized (Ultra-Turrax, Janke and Kunkel, Staufen, Germany) and total RNA was isolated by the acid guanidinium thiocyanate-phenol-chloroform extraction method [17]. The retina from two rats in the same study group were pooled to yield approximately $20 \mu \mathrm{g}$ of total RNA. The RNA containing nylon filters were then hybridized with the cDNA encoding mouse $\mathrm{VEGF}_{164}$. The VEGF cDNA probe was labelled with $\left[\alpha-{ }^{32} \mathrm{P}\right] \mathrm{dCTP}$ by random-primed DNA synthesis (Boehringer Mannheim, Mannheim, Germany) followed by northern analysis [18]. Intensity of hybridization was quantified using a phosphorescent imager (Fujix BASS 3000, Fuji Photo Film Co. Ltd, Tokyo, Japan) and all results were corrected for differences in RNA loading and transfer by rehybridization with an oligonucleotide probe for $18 \mathrm{~S}$ rRNA. Results were expressed as the ratio of image intensity of VEGF to $18 \mathrm{~S}$ relative to control retinae which were assigned arbitrarily a value of 1 . In addition, hybridized filters were also exposed to X-ray film with intensifying screens (Kodak X-Omat, Eastman Kodak, Rochester, N.Y., USA) at $-80^{\circ} \mathrm{C}$ for 14 days.

In situ hybridization. In situ hybridization was done using a cDNA encoding mouse VEGF VE4 $_{16}$ (gift of Dr S. Stacker, Ludwig Institute for Cancer Research, Melbourne, Australia) [19]. The fragment containing the entire open reading frame of VEGF (gift of Dr. S. Stacker) was cloned into pGEM 4Z (Promega, Maddison, Wis., USA) and linearized with Hind III to produce an antisense riboprobe using T7 RNA polymerase. In situ hybridization was as described previously [20] in animals outlined in Experiment 2. After removal of the eye, the globe was embedded in paraffin with the optic nerve head placed at $45^{\circ}$. Retinal sections were then cut perpendicularly from the posterior pole of the globe. The tenth $4 \mu \mathrm{m}$ section from each rat retina was selected for evaluation of gene expression. These $4 \mu \mathrm{m}$ thick sections cut from formalin-fixed paraffin-embedded eye tissue were placed onto slides precoated with 3-aminopropyltriethoxysilane and baked overnight at $37^{\circ} \mathrm{C}$. In situ hybridization was then done as described previously [21]. Sections hybridized with sense probe for VEGF was used as a control for non-specific binding. After hybridization, slides were washed in $2 \times \mathrm{SSC}$, rinsed, incubated with RNAse A, washed again in $2 \times$ SSC, dehydrated in graded ethanol, air dried and exposed to Kodak X-Omat autoradiographic film for 5 days. Slides were subsequently dipped in Ilford K5 nuclear emulsion (Ilford, Mobberley, Cheshire, UK), stored in a light-free box with desiccant at room temperature for 2 weeks, immersed in Kodak D19 developer, fixed in Ilford Hypam and stained with haematoxylin and eosin. 
Table 1. Clinical characteristics of study rats in experiment 2

\begin{tabular}{|c|c|c|c|c|}
\hline & Control & $\begin{array}{l}\text { Control + } \\
\text { perindopril }\end{array}$ & Diabetic & $\begin{array}{l}\text { Diabetic + } \\
\text { Perindopril }\end{array}$ \\
\hline Body weight (g) & $507 \pm 13$ & $461.5 \pm 12$ & $359 \pm 30^{\mathrm{a}}$ & $394 \pm 11^{\mathrm{a}}$ \\
\hline Plasma glucose $(\mathrm{mmol} / \mathrm{l})$ & $4.5 \pm 0.5$ & $5.3 \pm 0.3$ & $23.6 \pm 0.2^{\mathrm{a}}$ & $20.7 \pm 0.8^{\mathrm{a}}$ \\
\hline Systolic blood pressure (mmHg) & $129 \pm 3$ & $118 \pm 1^{\mathrm{a}}$ & $134 \pm 6$ & $118 \pm 3^{b, c}$ \\
\hline Albuminuria (mg/day) & $0.6 x / \div 1.2$ & $0.5 \mathrm{x} / \div 1.1$ & $10.0 \times / \div 1.6^{\mathrm{a}}$ & $1.2 \mathrm{x} / \div 1.3^{\mathrm{c}}$ \\
\hline Haematocrit (\%) & $42 \pm 3$ & $44 \pm 1$ & $42 \pm 1$ & $44 \pm 1$ \\
\hline
\end{tabular}

Data are shown as means \pm SEM except for albuminuria where geometric means $\mathrm{x} / \div$ tolerance factors are shown.

${ }^{\mathrm{a}} p<0.01$ vs control, ${ }^{\mathrm{b}} p<0.05$ vs control, ${ }^{\mathrm{c}} p<0.01$ vs diabetic

Quantitative autoradiography. The gene expression of VEGF was assessed by densitometric evaluation of autoradiographic images. Densitometry of autoradiographic images obtained by in situ hybridization was done by computer-assisted image analysis as described previously $[21,22]$ according to a reported method [23] using a micro computer imaging device (MCID, Imaging Research, St Catherine's, Ontario, Canada). In brief, in situ autoradiographic images were placed on a uniformly illuminating fluorescent light box (Northern Light Precision Luminator Model C60, Image Research, Ontario, Canada) and captured using a video camera (Sony Video Camera Module CCD, Tokyo, Japan) connected to an IBM AT computer with a $512 \times 512$ pixel array imaging board with 256 grey levels. After appropriate calibration by constructing a curve of optical density and radioactivity [24, 25] quantification of digitalized autoradiographic images was done using MCID software. Data were expressed as the ratio [in arbitray units (AU)] of the optical density (OD) relative to control retinae which were assigned a value of 1 . Tissue sections from all animals were exposed to x-ray film for 5 days and exposed to photographic emulsion for 14 days. All analyses were done with the observer masked to the animal study group.

Vascular permeability. Vascular permeability was measured at 24 weeks after the induction of experimental diabetes using a double isotope method [26, 27]. In brief, a permeation marker, ${ }^{125}$ I-human serum albumin, was injected intravascularly and allowed to circulate for $15 \mathrm{~min}$. This time is adequate to allow passage of the marker from the intravascular to the extravascular space but not in the reverse direction. After $13 \mathrm{~min}$, an intravascular marker, ${ }^{131}$ I-human serum albumin was injected and allowed to circulate for the final 2 min of the experiment, permitting the systemic distribution but not extravascular permeation of the marker. We prepared ${ }^{125} \mathrm{I}$-albumin by the chloramine-T method [28]. Rats were anaesthetized by intravenous injection of methohexital and amylobarbital. At 1 and $5 \mathrm{~min}, 0.2 \mathrm{ml}$ of blood was drawn by arterial cannula. At $13 \mathrm{~min}, 0.56-0.74 \mathrm{MBq}$ of ${ }^{131} \mathrm{I}$-albumin was injected intravenously and at $15 \mathrm{~min}$ a further blood sample was taken before the lethal injection of pentobarbitone. Ocular tissues were than rapidly removed and dissected to yield choroid-free retina as described previously [27]. The radioisotope content was measured by $\gamma$-spectroscopy (Crystal 5412/5424, United Technologies, Packard Cleveland, Queensland, Australia), corrected for background and isotope spill-over and related to tissue weight. An error of less than $2 \%$ was obtained by extending the counting period to $10 \mathrm{~min}$. The tissue to blood isotope ratio (TBIR) for retina was calculated from the tissue counts of the intravascular marker, ${ }^{131} \mathrm{I}$-albumin and from time-averaged counts of the permeation marker, ${ }^{125} \mathrm{I}$-albumin using the formula: TBIR $=\left[(\mathrm{cpm} \mathrm{PM})_{\text {tissue }} /(\mathrm{cpm} \mathrm{IM})_{\text {tissue }}\right] /\left[(\mathrm{cpm} \mathrm{PM})_{\text {blood }} /\right.$ $\left.\left(\begin{array}{ll}\mathrm{cpm} & \mathrm{IM}\end{array}\right)_{\text {blood }}\right]$ where $\mathrm{cpm}=$ emission counts per min, $\mathrm{PM}=$ permeation marker and $\mathrm{IM}=$ intravascular marker.

Statistics. Because of a positively skewed distribution albuminuria was logarithmically transformed before statistical analysis and expressed as geometric mean $\mathrm{x} / \div$ tolerance factor. Results of other variables are expressed as means \pm SEM unless stated otherwise. Data were analysed by ANOVA with comparisons between groups using Fisher's least significant difference method [29]. Analyses were done using the Statview $\mathrm{SE}+$ Graphics package (Abacus Concepts, Berkeley, Calif., USA) on an Apple G3 (Apple Computer, Cupertino, Calif., USA). A $p$ value less than 0.05 was considered statistically significant.

\section{Results}

Clinical data. In Experiment 1, all animals that had received STZ were diabetic [plasma glucose $>15 \mathrm{mmol} / \mathrm{l}$; plasma glucose: control (C) $6.1 \pm 0.1$, control + ramipril (CR) $7.8 \pm 0.2$, diabetic (D) 28.4, diabetes + ramipril $\quad$ (DR) $26.3 \pm 0.7 \mathrm{mmol} / \mathrm{l}$; $p<0.001 \mathrm{C}, \mathrm{CR}$ vs D, DR]. Glycated haemoglobin was higher in diabetic rats and unaffected by ramipril treatment (C $3.3 \pm 0.1$, CR $3.4 \pm 0.1$, D $10.6 \pm 0.6$, DR $11.1 \pm 0.3 \% ; p<0.001 \mathrm{C}, \mathrm{CR}$ vs $\mathrm{D}, \mathrm{DR})$. In ramipriltreated animals systolic blood pressure was similar to control animals and less than in untreated diabetic rats (albumin excretion rate: C $118 \pm 4, \mathrm{CR} 106 \pm 3$, D $129 \pm 3$, DR $113 \pm 5, p<0.01 \mathrm{C}$ vs CR, D vs DR). Similarly, in Experiment 2, rats that had received STZ were also all diabetic with no difference in $\mathrm{HbA}_{1 \mathrm{c}}$ between animals perindopril-treated and untreated diabetic animals (Table 1). Diabetes was associated with reduced body weight when compared with control animals and was not influenced by treatment with perindopril (Table 1). Perindopril treatment was, however, accompanied by albumin excretion rates and systolic blood pressure similar to control animals and significantly less than in untreated diabetic rats (Table 1$)$.

Northern blot analysis. Retinal VEGF gene expression was increased twofold in retinae of diabetic compared with control rats (control: $1.0 \pm 0.36$ vs diabetic $1.9 \pm 0.11 \mathrm{AU}, p<0.05)$. VEGF mRNA in ramipril- 


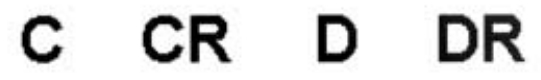

\section{VEGF}
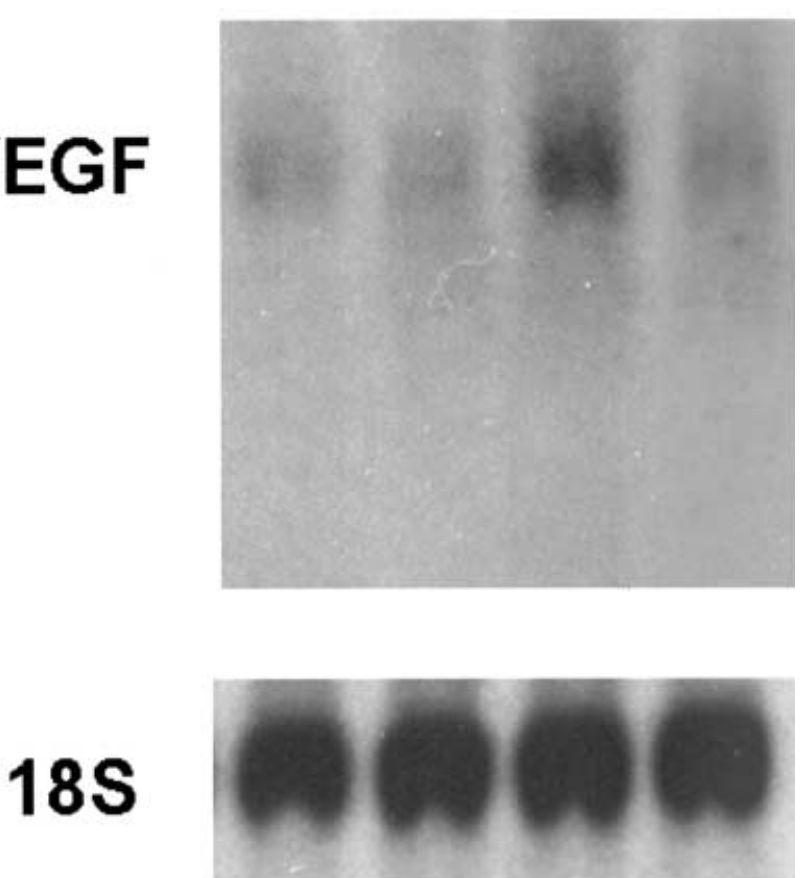

Fig.1. Northern blot of retinal VEGF mRNA in control (C), ramipril-treated control (CR), diabetic (D) and ramipril-treated diabetic (DR) rats. Increased gene expression of VEGF is seen in diabetic rats compared with control and ramipril-treated diabetic animals. No statistically significant change in $18 \mathrm{~S}$ rRNA was observed

treated diabetic rats was similar to that of control animals $(1.1 \pm 0.10)$ and less than in untreated diabetic rats $(p<0.05)$, (Figs. 1, 2). No difference in VEGF expression was noted between control and ramipriltreated controls.

In situ hybridization autoradiography. In situ hybridization autoradiography showed an increase in VEGF gene expression in the retina of diabetic rats compared with control animals (control, $166 \pm 9$ vs diabetic, $252 \pm 31$ OD units, $p<0.05$, Figs. 3 and 4 ). This overexpression was reduced in perindopriltreated diabetic rats to levels similar to those of control animals $(101 \pm 18$ OD units, $p<0.01$, Figs. 3 and $4)$. No difference in VEGF expression was noted between control and perindopril-treated control (132 \pm 12 OD units, Figs. 3 and 4), nor between control and perindopril-treated diabetic rats.

In situ hybridization microscopy. Intense expression of VEGF mRNA was noted in the ganglion cell layer, inner nuclear layer and retinal pigment epithelium (Fig.5). There was no change in the pattern of distribution of VEGF mRNA in diabetic and perindopril-treated diabetic rats compared with control animals.

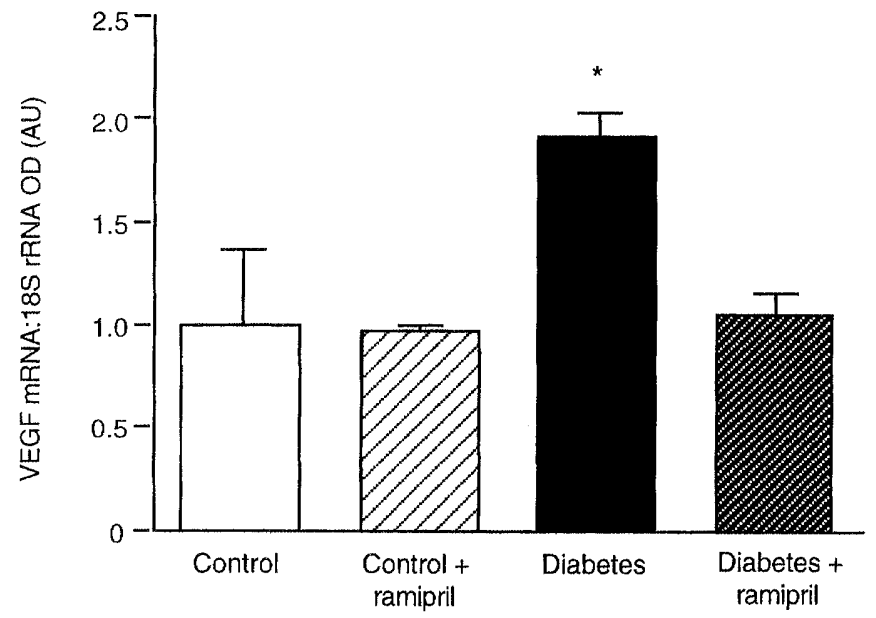

Fig. 2. Northern analysis of retinal VEGF mRNA in control and diabetic animals, with and without ramipril treatment. Data are expressed as means \pm SEM of the ratio of optical density (OD) in arbitrary units (AU) for VEGF mRNA relative to that of $18 \mathrm{~S}$ rRNA. ${ }^{*} p<0.05$ vs control, ramipril-treated diabetic rats and ramipril-treated controls

Retinal permeability. Diabetes was associated with a twofold increase in retinal tissue to blood isotope ratio (TBIR) compared with control animals (Fig.6). This diabetes-related retinal hyperpermeability was reduced by perindopril treatment (Fig. 6). Perindopril had no effect on TBIR in control rats.

\section{Discussion}

In the context of the recent description of the beneficial effects of ACE inhibitors in diabetic retinopathy [11], it is postulated that these drugs exert their retinoprotective effects through the modulation of VEGF expression. Our findings provide supportive in vivo evidence of an AII-VEGF axis within the retina which could be activated in certain pathological conditions such as diabetes. Furthermore, the inhibition of this pathway was associated with a reduction in retinal vascular hyperpermeability.

Although the angiogenic properties of VEGF have been the focus of much recent attention, this polypeptide growth factor was originally described as a tumour secretory product causing vascular leakage [30]. It has been found that VEGF is 50,000 times more potent than histamine as an enhancer of vascular permeability [31]. The role of VEGF in the pathogenesis of diabetic eye disease was initially shown 6 years ago with the finding that intraocular VEGF concentrations in patients with active proliferative retinopathy were statistically significantly higher than in diabetic patients without neovascularization [3,4]. In addition to being a specific endothelial cell mitogen, VEGF induces an angiogenic response in a variety of in vivo models including rabbit cornea [32] 


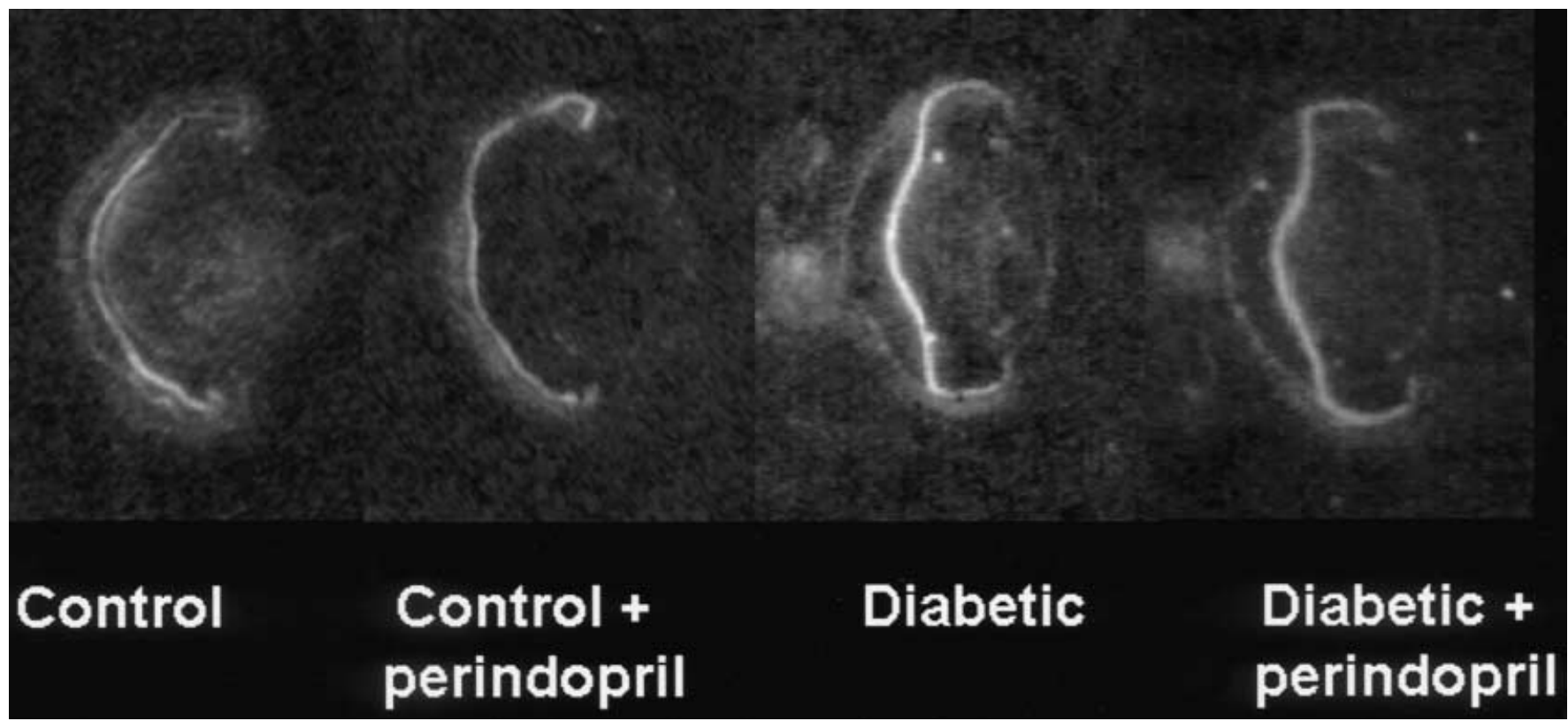

Fig. 3. Representative in situ hybridization autoradiographs for VEGF in retinas of (left to right) control, perindopril-treated control, diabetic and perindopril-treated diabetic animals. Magnification $\times 20$

and chicken chorioallantoic membrane [33]. Its role in angiogenesis has been further shown by the ability of soluble chimeric VEGF-binding proteins to suppress neovascularization [34]. More recently, examination of retinas from patients with non-proliferative diabetic retinopathy has also shown abundant immunostainable VEGF in the absence of anatomical evidence of retinal non-perfusion [2]. Studies in experimental animals have found VEGF and its receptors in the retina of normoglycaemic animals and also increased expression in association with the diabetic milieu [21, 35, 36].

Several factors implicated in the pathogenesis of diabetic retinopathy have been shown to increase VEGF expression. These include not only glucose [37] but also advanced glycation end products (AGEs) [38] and protein kinase-C activation [39, 40]. Of particular relevance to our study, angiotensin II also stimulates VEGF expression, an action mediated by the AT1 receptor as indicated by the attenuation of this effect by the AT1 receptor antagonist, losartan [13, 41]. Furthermore, in addition to its effects of on VEGF expression, angiotensin II also increases expression of VEGF Receptor-2 (VEGFR-2) [42] thereby potentially increasing tissue responses to VEGF. In addition, VEGF expression is also regulated by a number of other growth factors including platelet-derived growth factor, transforming growth factor- $\beta$ [43] and insulin-like growth factor-I (IGF-I) [44]. Recent studies suggest that interactions between
IGF-I and its receptors enhance the angiogenic effects of VEGF [45]. These findings are consistent with the documented association between IGF-I and diabetic retinopathy [46] and suggest that both IGFI and VEGF may contribute to the pathogenesis of vision-threatening retinal disease in diabetes. Thus, although a reduction in VEGF expression with ACE inhibitor treatment was noted in our study it is also possible that other intra-ocular growth factors such as IGF-I were also affected by modulation of the RAS as in the kidney [47].

Although diabetes in the rodent model is not associated with proliferative retinopathy it does develop increased retinal vascular permeability [27, 48, 49] in association with increased retinal VEGF expression

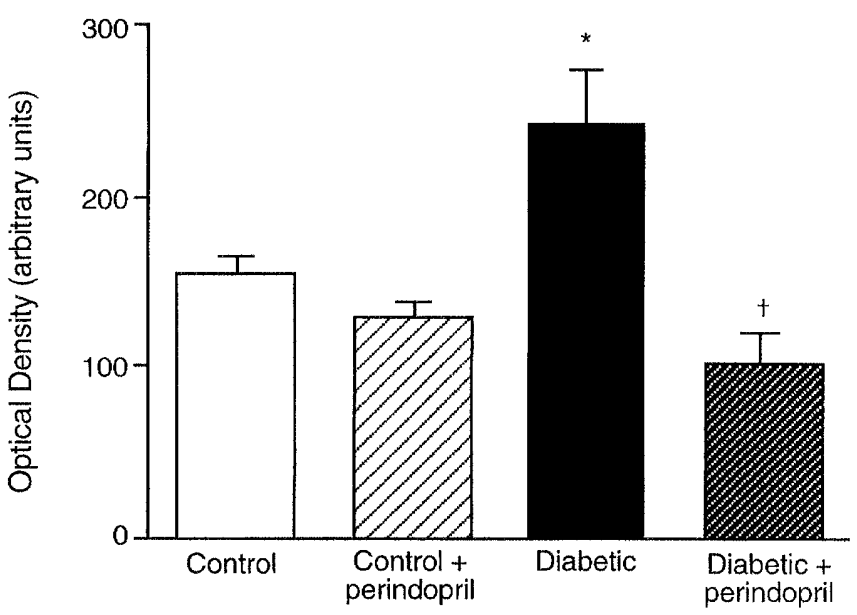

Fig. 4. Retinal gene expression of VEGF in control, perindopril-treated controls, diabetic and perindopril-treated diabetic animals as assessed by quantitative densitometry of in situ hybridization autoradiographs. Data are shown as means \pm SEM. $* p<0.05$ vs control, $\uparrow p<0.01$ vs diabetic 


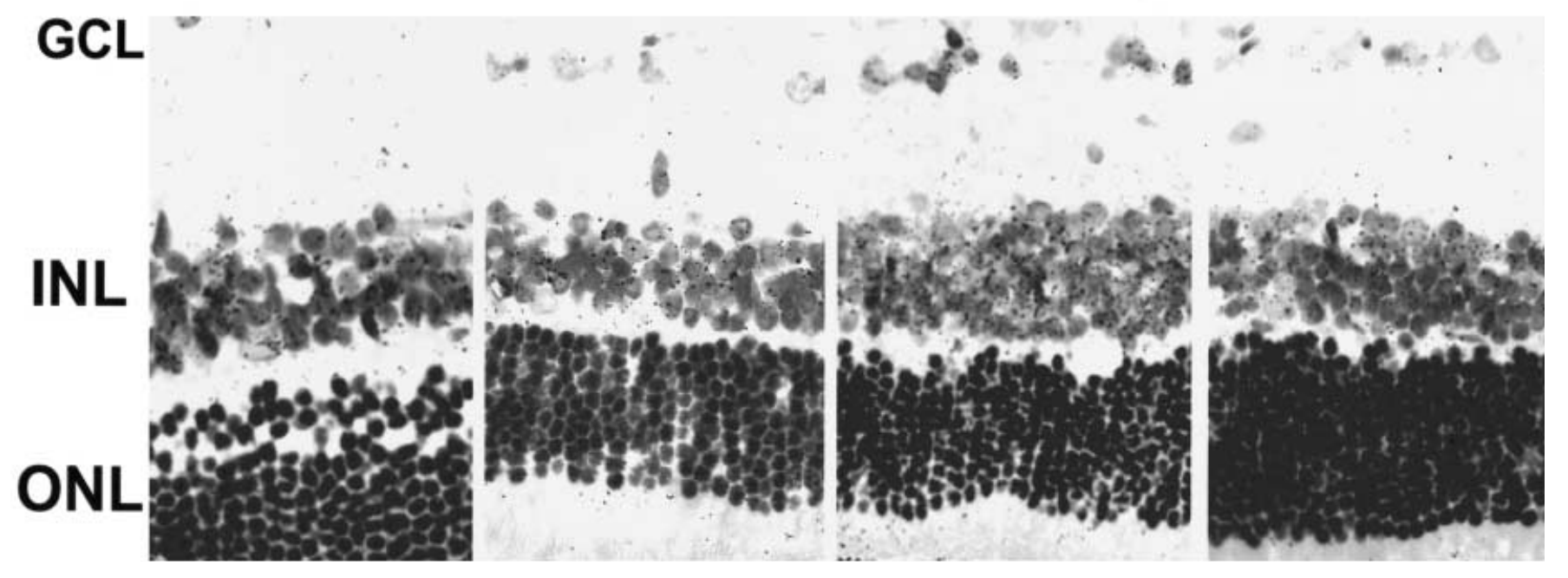

Fig. 5. Bright-field photomicrographs showing VEGF expression in $3 \mu \mathrm{m}$ paraffin sections of retina (left to right) from control, perindopril-treated control, diabetic and perindopriltreated diabetic rats. Sections are counterstained with haematoxylin and eosin. GCL, ganglion cell layer; INL, inner nuclear layer; RPE, retinal pigment epithelium. Increased VEGF mRNA was observed in diabetic rats in the GCL and INL compared with control, perindopril-treated control and perindopril-treated diabetic rats. Magnification $\times 340$

$[21,50]$. In adult primates intravitreal injections of VEGF leads to many of the changes associated with non-proliferative diabetic including oedema, microaneurysms and intraretinal haemorrhages [51] suggesting that VEGF has a key role in non-proliferative as well as proliferative retinopathy.

The presence of a local as distinct from a systemic renin-angiotensin system (RAS) has been established in several organ systems $[52,53]$ including the eye where the presence of all components of the RAS including its receptors have been identified [8, 54-56]. The beneficial effect of ACE inhibition on retinopathy in patients with diabetes was recently shown in the EUCLID study where treatment with lisinopril was associated with a statistically significant reduction in the progression of retinopathy [11] confirming the results of several earlier trials with ACE inhibitors in which the benefits achieved approached but did not reach pre-defined levels of statistical significance [60-62]. Epidemiological, clinical course and intervention studies have all shown a positive relation between blood pressure and both the incidence and progression of diabetic retinopathy [63-65]. Furthermore, cell stretch, an in vitro counterpart of hypertension leads to increased VEGF expression [66]. Thus, it is possible that the effects of ACE inhibition on vascular permeability and VEGF expression, as shown in our study, followed a reduction in systemic blood pressure rather than a specific effect on the RAS.
In our study ACE inhibition reduced the overexpression of VEGF and vascular permeability in the retinas of diabetic rats, providing a potential mechanistic link between diabetes, VEGF and the therapeutic effects of blockade of the renin-angiotensin system in diabetic retinal disease.

Acknowledgements. We thank Christos Tikellis for his expert assistance with molecular biological studies and Professor Hugh Taylor for his advice and supervision. Studies were supported by grants from the Juvenile Diabetes Foundation International and the National Health and Medical Research Council of Australia. Dr. R. E. Gilbert is a recipient of a Career Development Award and Dr. D. J. Kelly is a recipient of a postdoctoral fellowship both from the Juvenile Diabetes Foundation International.

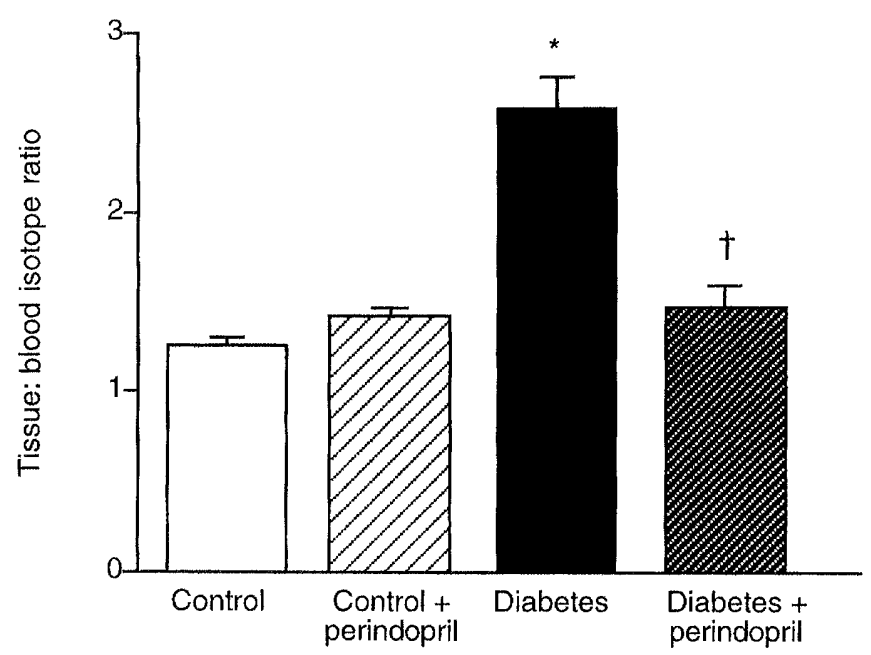

Fig. 6. Retinal vascular permeability in control, diabetic and perindopril-treated diabetic animals. Data are shown as means \pm SEM. ${ }^{*} p<0.01$ control vs diabetic, $\dagger p<0.01$ diabetic vs diabetic + perindopril 


\section{References}

1. Sjolie AK, Stephenson J, Aldington S et al. (1997) Retinopathy and Vision Loss in Insulin Dependent Diabetes in Europe - the Eurodiab IDDM Complications Study. Ophthalmology 104: 252-260

2. Amin RH, Frank RN, Kennedy A, Eliott D, Puklin JE, Abrams GW (1997) Vascular endothelial growth factor is present in glial cells of the retina and optic nerve of human subjects with nonproliferative diabetic retinopathy. Invest Ophthalmol Vis Sci 38: 36-47

3. Adamis AP, Miller JW, Bernal MT et al. (1994) Increased vascular endothelial growth factor levels in the vitreous of eyes with proliferative diabetic retinopathy. Am J Ophthal 118: 445-450

4. Aiello LP, Avery RL, Arrigg PG et al. (1994) Vascular endothelial growth factor in ocular fluid of patients with diabetic retinopathy and other retinal disorders. N Engl J Med 331: 1480-1487

5. Anderson S, Jung FF, Ingelfinger JR (1993) Renal reninangiotensin system in diabetes: functional, immunohistochemical, and molecular biological correlations. Am J Physiol 265: F477-F486

6. Lewis EJ, Hunsicker LG, Bain RP, Rohde RD, for the Collaborative Study Group (1993) The effect of angiotensinconverting-enzyme inhibition on diabetic nephropathy. N Engl J Med 329: 1456-1462

7. Estacio RO, Jeffers BW, Hiatt WR, Biggerstaff SL, Gifford SL, Schrier RW (1998) The effect of nisoldipine as compared with enalapril on cardiovascular outcomes in patients with non-insulin-dependent diabetes and hypertension. N Engl J Med 338: 645-652

8. Berka JL, Stubbs AJ, Wang DZ et al. (1995) Renin-containing Muller cells of the retina display endocrine features. Invest Opthalmol Vis Sci 36: 1450-1458

9. Danser AH, van den Dorpel MA, Deinum J et al. (1989) Renin, prorenin, and immunoreactive renin in vitreous fluid from eyes with and without diabetic retinopathy. J Clin Endocrinol Metab 68: 160-167

10. Danser AH, Derkx FH, Admiraal PJ, Deinum J, Dejong P, Schalekamp M (1994) Angiotensin Levels in the Eye. Invest Ophthalmol Vis Sci 35: 1008-1018

11. Chaturvedi N, Sjolie A-K, Stephenson JM et al. (1998) Effect of lisinopril on progression of retinopathy in normotensive people with type 1 diabetes. Lancet 351: 28-31

12. Williams B, Baker AQ, Gallacher B, Lodwick D (1995) Angiotensin II increases vascular permeability factor gene expression by human vascular smooth muscle cells. Hypertension 25: 913-917

13. Chua CC, Hamdy RC, Chua BH (1998) Upregulation of Vascular Endothelial Growth Factor By Angiotensin II in Rat Heart Endothelial Cells. Biochim Biophys Acta 1401: 187-194

14. Jerums G, Allen TJ, Cooper ME (1989) Triphasic changes in selectivity with increasing proteinuria in type I and type II diabetes. Diabetic Med 6: 772-779

15. Schmidt FH (1961) Enzymatic determination of glucose and fructose simultaneously. Klin Wochenschr 39: 1244-1247

16. Allen TJ, Cooper ME, O'Brien RC, Bach LA, Jackson B, Jerums G (1990) Glomerular filtration rate in the streptozocin diabetic rat: The role of exchangeable sodium, vasoactive hormones and insulin therapy. Diabetes 38: 1182-1190

17. Chomczynski P, Sacchi N (1987) Single-step method of RNA isolation by acid guanidinium thiocyanate-phenolchloroform extraction. Anal Biochem 162: 156-159
18. Rumble JR, Cooper ME, Soulis T et al. (1997) Vascular hypertrophy in experimental diabetes: role of advanced glycation end products. J Clin Invest 99: 1016-1027

19. Shima DT, Kuroki M, Deutsch U, Ng YS, Adamis AP, Damore PA (1996) The Mouse Gene For Vascular Endothelial Growth Factor - Genomic Structure, Definition of the Transcriptional Unit, and Characterization of Transcriptional and Post-Transcriptional Regulatory Sequences. Journal of Biol Chem 271: 3877-3883

20. Gilbert RE, McNally PG, Cox A et al. (1995) SPARC gene expression is reduced in early diabetes related kidney growth. Kidney Int 48: 1216-1225

21. Gilbert RE, Vranes D, Berka JL et al. (1998) Vascular Endothelial Growth Factor and Its Receptors in Control and Diabetic Rat Eyes. Lab Invest 78: 1017-1027

22. Wu L, Cox A, Roe C, Dziadek M, Cooper ME, Gilbert RE (1997) Transforming growth factor $\beta 1$ and renal injury following subtotal nephrectomy in the rat: Role of the reninangiotensin system. Kidney Int 51: 1553-1567

23. Baskin DG, Stahl W (1993) Fundamentals of quantitative autoradiography by computer densitometry for in situ hybridization with emphasis on ${ }^{33} \mathrm{P}$. J Histochem Cytochem 41: 1767-1773

24. Mendelsohn FA, Dunbar M, Allen A et al. (1987) Localization of angiotensin II receptors in rat and monkey kidney by in vitro autoradiography. Kidney Int [Suppl 31]: S40-S44

25. Wookey PJ, Tikellis C, Du H-C, Qin H-F, Sexton PM, Cooper ME (1996) Amylin binding in rat renal cortex, stimulation of adenyl cyclase and activation of plasma renin. Am J Physiol 270: F289-F294

26. Pugliese G, Tilton RG, Speedy A et al. (1989) Effects of very mild versus overt diabetes on vascular hemodynamics and barrier function in rats. Diabetologia 32: 845-857

27. Gin T, Joon TL, Panagiotopoulos S, Cooper ME, Taylor H, Jerums G (1996) Organ specificity of antihypertensive therapy on ocular albumin vascular clearance and albuminuria in the hypertensive diabetic rat. Invest Ophthalmol Vis Sci 37: 281-289

28. Greenwood FC, Hunter WM, Glover JS (1963) Preparation of 131I-labelled human growth hormone of high specific radioactivity. Biochem J 89: 114-123

29. Snedecor GW, Cochran WG (1980) Statistical Methods. Iowa State University Press, Iowa, pp 228-236

30. Senger DR, Galli SJ, Dvorak AM, Perruzzi CA, Harvey VS, Dvorak HF (1983) Tumor cells secrete a vascular permeability factor that promotes accumulation of ascites fluid. Science 219: 983-985

31. Senger DR, Connolly DT, Van De Water L, Feder J, Dvorak HF (1990) Purification and NH-terminal amino acid sequence of guinea pigtumor-secreted vascular permeability factor. Cancer Res 50: 1774-1778

32. Phillips GD, Stone AM, Jones BD, Schultz JC, Whitehead RA, Knighton DR (1994) Vascular endothelial growth factor (rhVEGF165) stimulates direct angiogenesis in the rabbit cornea. In Vivo 8: 961-965

33. Leung D, Cachianes G, Kuang W-J, Goeddel D, Ferrara N (1989) Vascular endothelial growth factor is a secreted angiogenic mitogen. Science 246: 1306-1309

34. Aiello LP, Pierce EA, Foley ED et al. (1995) Suppression of retinal neovascularization in vivo by inhibition of vascular endothelial growth factor (VEGF) using soluble VEGF-receptor chimeric proteins. Proc Natl Acad Sci USA 92: 10457-10461

35. Murata T, Kakagawa K, Khalil A, Ishibashi T, Inomata H, Sueshi K (1996) The relation between expression of vascular endothelial growth factor and breakdown of the bloodretinal barrier in diabetic rat retinas. Lab Invest 74: 819-825 
36. Hammes H-P, Lin J, Bretzel RG, Brownlee M, Breier G (1998) Upregulation of vascular endothelial growth factor/ vascular endothelial growth factor receptor system in experimental background diabetic retinopathy of the rat. Diabetes 47: 401-406

37. Williams B (1997) Factors regulating the expression of vascular permeability/vascular endothelial growth factor by human vascular tissues. Diabetologia 40: S118-S120

38. Lu M, Kuroki M, Amano S et al. (1998) Advanced Glycation End Products Increase Retinal Vascular Endothelial Growth Factor Expression. J Clin Invest 101: 1219-1224

39. Williams B, Gallacher B, Patel H, Orme C (1997) Glucoseinduced protein kinase $C$ activation regulates vascular permeability factor mRNA expression and peptide production by human vascular smooth muscle cells in vitro. Diabetes 46: 1497-1503

40. Aiello LP, Bursell S-E, Clermont A et al. (1997) Vascular endothelial growth factor-induced retinal permeability is mediated by protein kinase $\mathrm{C}$ in vivo and supressed by an effective orally active $\beta$-isoform-selective inhibitor. Diabetes 46: $1473-1480$

41. Williams B, Baker AQ, Gallacher B, Lodwick D (1995) Angiotensin Ii Increases Vascular Permeability Factor Gene Expression By Human Vascular Smooth Muscle Cells. Hypertension 25: 913-917

42. Otani A, Takagi H, Suzuma K, Honda Y (1998) Angiotensin II potentiates vascular endothelial growth factor-induced angiogenic activity in retinal microcapillary endothelial cells. Circ Res 82: 619-628

43. Brogi E, Wu T, Namiki A, Isner JM (1994) Indirect angiogenic cytokines upregulate VEGF and bFGF gene expression in vascular smooth muscle cells, whereas hypoxia upregulates VEGF expression only. Circulation 90: 649-652

44. Miele C, Rochford JJ, Filippa N, Giorgetti-Peraldi S, Van Obberghen E (2000) Insulin and Insulin-like Growth Factor-I Induce Vascular Endothelial Growth Factor mRNA Expression via Different Signaling Pathways. J Biol Chem 275: 21695-21702

45. Smith LE, Shen W, Perruzzi C et al. (1999) Regulation of vascular endothelial growth factor-dependent retinal neovascularization by insulin-like growth factor-1 receptor. Nat Med 5: 1390-1395

46. Meyer-Schwickerath R, Pfeiffer A, Blum WF et al. (1993) Vitreous levels of the insulin-like growth factors I and II, and the insulin-like growth factor binding proteins 2 and 3, increase in neovascular eye disease. Studies in nondiabetic and diabetic subjects. J Clin Invest 92: 2620-2625

47. Szabo A, Lutz J, Schleimer K et al. (2000) Effect of angiotensin-converting enzyme inhibition on growth factor mRNA in chronic renal allograft rejection in the rat. Kidney Int 57: 982-991

48. Williamson JR, Chang K, Tilton RG et al. (1987) Increased vascular permeability in spontaneously diabetic BB/W rats and in rats with mild versus severe streptozotocin-induced diabetes. Diabetes 36: 813-821

49. Tilton RG, Pugliese G, Faller AM, LaRose LS, Province MA, Williamson JR (1992) Interaction between hypertension and diabetes on vascular function and structure in rats. J Diabetes Complications 6: 187-196

50. Sone H, Kawakami Y, Okuda Y et al. (1997) Ocular vascular endothelial growth factor in diabetic rats are elevated before observable retinal proliferative changes. Diabetologia 40: 726-730

51. Tolentino MJ, Miller JW, Gragoudas ES et al. (1996) Intravitreous Injections of Vascular Endothelial Growth Factor
Produce Retinal Ischemia and Microangiopathy in an Adult Primate. Ophthalmology 103: 1820-1828

52. Deschepper CF, Mellon SH, Cumin F, Baxter JD, Ganong WF (1986) Analysis by immunocytochemistry and in situ hybridization of the distribution of or renin and its mRNA in kidney, testis, adrenal, and pituitary of the rat. Proc Natl Acad Sci USA 83: 7552-7556

53. Dzau VJ, Ellison KE, Brody T, Ingelfinger J, Pratt RE (1987) A comparative study of the distribution of renin and angiotensinogen messenger ribonucleic acids in rat and mouse tissues. Endocrinology 120: 2334-2338

54. Kohler K, Wheelerschilling T, Jurklies B, Guenther E, Zrenner E (1997) Angiotensin II in the Rabbit Retina. Vis Neurosci 14: 63-71

55. Murata M, Nakagawa M, Takahashi S (1997) Angiotensinogen mRNA Is Synthesized Locally in Rat Ocular Tissues. Ophthalmologica 211: 301-304

56. Wagner J, Danser AH, Derkx FH et al. (1996) Demonstration of Renin Mrna, Angiotensinogen mRNA, and Angiotensin Converting Enzyme mRNA Expression in the $\mathrm{Hu}-$ man Eye - Evidence For an Intraocular Renin-Angiotensin System. Br J Ophthalmol 80: 159-163

57. Murata M, Nakagawa M, Takahashi S (1997) Expression and Localization of Angiotensin II Type 1 Receptor mRNA in Rat Ocular Tissues. Ophthalmologica 211: 384-386

58. Sato T, Niwa M, Himeno A, Tsutsumi K, Amemiya T (1993) Quantitative Receptor Autoradiographic Analysis For Angiotensin-II Receptors in Bovine Retinal Microvessels - Quantitation With Radioluminography. Cell Mol Neurobiol 13: 233-245

59. Ottlecz A, Bensaoula T, Eichberg J, Peterson RG (1996) Angiotensin-Converting Enzyme Activity in Retinas of Streptozotocin-Induced and Zucker Diabetic Rats - the Effect of Angiotensin II On Na + , K + -AtPase Activity. Invest Ophthalmol Vis Sci 37: 2157-2164

60. Chase HP, Garg SK, Harris S, Hoops S, Jackson WE, Holmes DL (1993) Angiotensin converting enzyme inhibitor treatment for young normotensive diabetic subjects: a two-year trial. Ann Ophthalmol 25: 284-289

61. Larsen M, Hommel E, Parving H-H, Lund-Andersen H (1990) Protective effects of captopril on the blood-retina barrier in normotensive insulin-dependent diabetic patients with nephropathy and background retinopathy. Graefes Arch Clin Exp Ophthalmol 228: 505-509

62. Ravid M, Savin H, Jutrin I, Bental T, Katz B, Lishner M (1993) Long-term stabilizing effect of angiotensin-converting enzyme inhibition on plasma creatinine and on proteinuria in normotensive type II diabetic patients. Ann Intern Med 118: 577-581

63. Knowler WC, Bennett PH, Ballintine EJ (1980) Increased incidence of retinopathy in diabetics with elevated blood pressure. A six-year follow-up study in Pima Indians. N Engl J Med 302: 645-650

64. Klein BE, Klein R, Moss SE, Palta M (1995) A cohort study of the relationship of diabetic retinopathy to blood pressure. Arch Ophthalmol 113: 601-606

65. Group UKPDS (1998) Tight blood pressure control and risk of macrovascular and microvascular complications in type 2 diabetes: UKPDS 38. BMJ 317: 703-713

66. Gruden G, Thomas S, Burt D et al. (1997) Mechanical stretch induces vascular permeability factor in human mesangial cells: mechanisms of signal transduction. Proc Natl Acad Sci USA 94: 12112-12116 